\title{
MENINGKATKAN KEMAMPUAN PEMECAHAN MASALAH MATEMATIS SISWA SMP DENGAN MODEL PEMBELAJARAN THINK TALK WRITE.
}

\author{
Astrid Chandra Sari ${ }^{1}$ \\ Universitas Nahdlatul Ulama Sunan Giri, astridchandra05@unugiri.ac.id ${ }^{1}$ \\ Received : 15 Maret 2018, Accepted : 1 April 2018, ( Mathematics Education Unugiri 2018
}

\begin{abstract}
The purpose of this research are to know whether the average problem solving abilities matematis of students who were taught using Think Talk write learning model can achieve exhaustiveness learning and whether the average problem solving abilities matematis of students who were taught using Think Talk write learning model are better than average the average problem solving ability of students who were taught using the learning model of konvensional. The population in this research is VII grade students of SMP N 1 Klambu. By random sampling technique obtained two classes as a research sample, namely class VIIC as the experimental class and class VII B as the control class. The data was collected by the documentation methods, test methods and observation methods. Based on the analysis of research results is known that $83,3 \%$ of students who were taught using Think Talk write learning model can achieve exhaustiveness learning. In addition, there are significant differences between the average problem solving abilities matematis of students who were taught using the learning model of Think Talk write with students who are taught using the learning model of konvensional. From the above description it can be concluded that the application of Think Talk write learning model is effective towards problem solving ability matematis of VII grade students of SMP N 1 Klambu at the material quadrilateral.
\end{abstract}

Keywords: Problem solving ability matematis, Think Talk Write.

\begin{abstract}
Abstrak
Penelitian ini bertujuan untuk mengetahui apakah rata-rata kemampuan pemecahan masalah matematis siswa yang diajar menggunakan model pembelajaran Think Talk write dapat mencapai ketuntasan belajar dan apakah ratarata kemampuan pemecahan masalah matematis siswa yang diajar menggunakan model pembelajaran Think Talk write lebih baik daripada rata-rata kemampuan pemecahan masalah matematis siswa yang diajar menggunakan model pembelajaran konvensional. Populasi dalam penelitian ini adalah peserta didik kelas VII SMP N 1 Klambu. Dengan teknik random sampling diperoleh dua kelas sebagai sampel penelitian yaitu kelas VII C sebagai kelas eksperimen dan kelas VII B sebagai kelas kontrol. Pengumpulan data dilakukan dengan metode dokumentasi, metode tes dan metode observasi. Berdasarkan analisis hasil penelitian diketahui bahwa 83,3\% siswa yang diajar menggunakan model pembelajaran Think Talk write mencapai ketuntasan belajar. Selain itu, terdapat perbedaan yang signifikan antara ratarata kemampuan pemecahan masalah matematis siswa yang diajar menggunakan model pembelajaran Think Talk write dengan siswa yang diajar menggunakan model pembelajaran konvensional. Dari uraian di atas dapat disimpulkan bahwa penerapan model pembelajaran Think Talk write efektif terhadap kemampuan pemecahan masalah matematis siswa kelas VII SMP N 1 Klambu pada materi segiempat.
\end{abstract}

Kata kunci: Kemampuan Pemecahan Masalah Matematis, Think Talk Write.

\section{Pendahuluan}

Pendidikan sebagai proses yang berlangsung secara dinamis selalu berkembang sesuai dengan tuntutan kebutuhan masyarakat.
Keberhasilan suatu proses pengajaran matematika di samping tergantung pada kemampuan pengajar dalam mengajar juga tergantung pada siswa. Misalnya, bagaimana 
kemampuan pemecahan masalah matematis siswa untuk menyelesaikan sebuah soal. Pada kenyataannya sebagian besar siswa mempunyai tingkat perhatian dan kemampuan pemahaman yang berbeda terhadap pelajaran matematika. Mungkin pada dasarnya siswa mengetahui maksud dan tujuan dari pembelajaran matematika, serta memahami materi, namun karena matematika bersifat abstrak serta monoton kebanyakan siswa kesulitan jika harus menuliskan sendiri gagasan dan pemikiranpemikiran mereka sendiri. Ini diperkuat dengan rendahnya nilai ulangan harian dan tengah semester mata pelajaran matematika.

Berdasarkan hasil wawancara dengan salah satu guru matematika kelas VII di SMP N 1 Klambu, dapat diketahui bahwa siswa mengalami kesulitan dalam menyelesaikan soal-soal bertipe pemecahan masalah matematis dan menerjemahkan soal kehidupan sehari-hari ke model matematika, terutama pada materi yang bersifat abstrak seperti materi segiempat. Dari nilai ulangan peserta didik pada materi segiempat, tercatat rata-rata keseluruhan dari 5 kelas hanya 53\% siswa yang mencapai Kriteria Ketuntasan Minimal. Berdasarkan hal tersebut, dapat disimpulkan bahwa siswa sulit memahami konsep-konsep matematika karena konsep-konsep matematika tersebut bersifat abstrak. Selain itu interaksi dalam proses pembelajaran masih rendah, kebanyakan siswa tidak mau bertanya apabila ada materi yang belum sepenuhnya mengerti, sehingga pengajar sulit memahami kemampuan pemecahan masalah matematis siswa terhadap konsep matematika yang mereka pelajari.

Berkaitan dengan uraian di atas, maka perlu dilakukan perubahan dalam model pembelajaran model pembelajaran matematika, diharapkan model tersebut dapat menjadi wadah bagi siswa dan dapat membantu siswa sehingga siswa mampu memecahkan masalah dan dapat memberikan hasil belajar yang memuaskan. Salah satu wadah yang sesuai adalah penggunaan model pembelajaran Think Talk Write. Belajar dalam model pembelajaran Think Talk write memberikan kesempatan kepada siswa untuk memulai belajar dengan memahami permasalahan terlebih dahulu, kemudian terlibat secara aktif dalam diskusi kelompok, dan akhirnya menuliskan dengan bahasa sendiri hasil belajar yang diperolehnya [1]. Selain itu model pembelajaran Think Talk write dapat diterapkan pada siswa kelas yang sedang mengalami peralihan, siswa yang kebanyakan belum mandiri dan tidak mempunyai kemampuan percaya diri, padahal siswa harus siap menerima materi-materi yang baru.

Model pembelajaran Think Talk write merupakan suatu model pembelajaran untuk melatih ketrampilan siswa dalam berbicara dan menulis. Menekankan perlunya siswa mengomunikasikan hasil pemikiran matematikanya. Model pembelajaran Think Talk write diperkenalkan oleh Huinker. Model pembelajaran ini menekankan perlunya siswa mengkomunikasikan hasil pemikiran matematikanya. Model pembelajaran ini diawali dengan siswa membaca dan mencoba memahami masalah yang diberikan, diikuti dengan pemikiran selesaian dari suatu masalah matematika yang diberikan, kemudian diikuti dengan siswa mengkomunikasikan selesaian yang diperolehnya, dan akhirnya melalui diskusi serta negosiasi, siswa dapat menuliskan kembali hasil dari pemikirannya tersebut [3].

Setiap kegiatan belajar, pasti mempunyai tujuan yang ingin dicapai atau ada hasilnya. Jika kita belajar matematika maka kita akan mendapatkan hasil dari belajar metematika. Hasil belajar matematika dapat meliputi aspek kognitif, afektif, dan psikomotorik. Hasil belajar kognitif diperoleh dari tes. Sampai saat ini hasil tes matematika siswa masih relatif sangat rendah. Banyak hal yang melatarbelakangi masalah tersebut, misalnya matematika sulit karena banyak rumus, sulit untuk dipahami, dan lain-lain. Begitu juga dengan materi segiempat, siswa masih sulit memahami sifat-sifat segiempat. Untuk mengatasi masalah-masalah diatas, diterapkan model pembelajaran Think Talk write yang diduga dapat meningkatkan rata-rata hasil belajar siswa. Dengan model pembelajaran Think Talk write siswa dapat 
mengkonstruksi pengetahuannya sendiri, mengkomunikasikan pemikirannya, dan menuliskan diskusinya sehingga siswa lebih memahami konsep yang diajarkan dan membuat siswa terbiasa mengkomunikasikan ide-ide secara lisan maupun tulisan dalam rangka memecahkan suatu masalah matematika.

Dari penjelasan di atas, muncul permasalahan: (1) apakah rata-rata kemampuan pemecahan masalah matematis siswa yang diajar menggunakan model pembelajaran Think Talk write dapat mencapai ketuntasan belajar?, (2) apakah rata-rata kemampuan pemecahan masalah matematis siswa yang diajar menggunakan model pembelajaran Think Talk write lebih baik daripada rata-rata kemampuan pemecahan masalah matematis siswa yang diajar menggunakan model pembelajaran konvensional?

Berdasarkan permasalahan tersebut, maka tujuan dari penelitian ini adalah untuk mengetahui keefektifan model pembelajaran Think Talk write dalam mencapai ketuntasan belajar siswa dan untuk mengetahui apakah rata-rata kemampuan pemecahan masalah matematis siswa yang diajar menggunakan model pembelajaran Think Talk write lebih baik daripada siswa yang diajar menggunakan model pembelajaran konvensional.

\section{Metode Penelitian}

Populasi adalah keseluruhan subyek penelitian [2]. Populasi dalam penelitian ini adalah siswa kelas VII semester 2 SMP Negeri 1 Klambu kabupaten Grobogan, terdiri dari 5 kelas yaitu VII A, VII B, VII C, VII D, dan VII E. Pada penelitian ini peneliti menerapkan metode eksperimen, yang dengan cara ini peneliti sengaja menimbulkan suatu kejadian atau keadaan, kemudian diteliti bagaimana akibatnya. Dengan kata lain, eksperimen adalah suatu cara untuk mencari hubungan sebab akibat (hubungan kausal) antara dua faktor yang sengaja ditimbulkan oleh peneliti dengan mengeliminasi atau mengurangi atau menyisihkan faktor-faktor lain yang mengganggu [2]. Desain penelitian tersebut dapat ditunjukkan pada tabel 1 berikut ini.

Tabel 1. Desain Penelitian

\begin{tabular}{lll}
\hline Kelompok & \multicolumn{1}{c}{ Perlakuan } & Tes \\
\hline Eksperimen & $\begin{array}{l}\text { Pembelajaran } \\
\text { dengan } \\
\text { menggunakan } \\
\text { model }\end{array}$ & $\begin{array}{l}\text { Tes } \\
\text { objektif }\end{array}$ \\
& \\
& pembelajaran & \\
& Think Talk Write. & \\
\hline Kontrol & $\begin{array}{l}\text { Pembelajaran } \\
\text { dengan model }\end{array}$ & Tes objektif \\
& pembelajaran & \\
& konvensional. & \\
\hline
\end{tabular}

Menurut Arikunto [2] sampel adalah sebagian atau wakil populasi yang diteliti. Pengambilan sampel dalam penelitian ini menggunakan tekhnik cluster random sampling. Dalam hal ini dipilih 2 kelas sebagai sampel penelitian yaitu kelas VII C sebagai kelas eksperimen dan kelas VII B sebagai kelas kontrol. Kelompok kelas eksperimen dikenai model pembelajaran Think Talk write dan pada kelompok kelas kontrol dikenai model pembelajaran konvensional. Selain itu dipilih satu kelas lagi yaitu kelas VII D sebagai kelas uji coba yaitu kelas yang telah mendapatkan materi yang digunakan saat penelitian.

Menurut Sukestiyarno [4] variabel adalah suatu karakteristik dari suatu objek yang nilainya untuk tiap objek bervariasi dan dapat diamati atau dihitung, atau diukur. Sesuai dengan permasalahan yang sudah dirumuskan, maka variabel dalam penelitian ini adalah nilai kemampuan pemecahan masalah matematis siswa. Teknik pengambilan data dalam penelitian ini menggunakan metode dokumentasi, metode tes dan metode observasi. Penelitian ini diawali dengan pelaksanaan pembelajaran pada kedua kelompok dengan materi segiempat yang dibatasi oleh keliling dan luas jajargenjang, persegi panjang, dan persegi. Dalam penyampaian materi tersebut kedua kelompok 
dikenai model pembelajaran yang berbeda, yakni model pembelajaran Think Talk write dengan pada kelompok eksperimen dan model pembelajaran konvensional pada kelompok kontrol. Pada akhir pembelajaran, kedua kelompok dilakukan tes untuk mengetahui hasil belajar aspek kemampuan pemecahan masalah matematis siswa. Tes dilakukan pada kelompok eksperimen dan kelompok kontrol dengan soal dan bobot yang sama. Soal evaluasi tersebut adalah tes tertulis berbentuk uraian sebanyak 7 butir soal dengan alokasi waktu 80 menit. Soal evaluasi yang digunakan adalah soal yang telah diujicobakan pada kelas uji coba sebelumnya dengan mengambil soal-soal yang valid, reliabel dan daya pembedanya signifikan. Pada akhir pembelajaran setelah diadakan penelitian dilakukan serangkaian pengujian untuk menguji hipotesis.

\section{Hasil dan Pembahasan}

Berdasarkan analisis data awal penelitian, menunjukkan bahwa kelompok eksperimen dan kelompok kontrol berangkat dari kondisi awal yang sama, yaitu setelah diadakan uji normalitas dan uji homogenitas yang menunjukkan bahwa kedua sampel berdistribusi normal dan tidak ada perbedaan varians yang signifikan, serta uji kesamaan dua rata-rata yang menunjukkan bahwa kedua sampel mempunyai kesepadanan. Selanjutnya masing-masing kelas sampel diberikan perlakuan yang berbeda, kelas eksperimen dikenai pembelajaran dengan model pembelajaran Think Talk Write, sedangkan kelas kontrol dikenai model pembelajaran konvensional.

Pembelajaran yang dilaksanakan berjalan sesuai dengan rencana pembelajaran yang dibuat. Pada kelas eksperimen yang diberi perlakuan dengan model pembelajaran Think Talk write rencana pembelajran yang dibuat sudah memenuhi sintak atau alur dari pembelajaran Think Talk Write, salah satunya ditunjukan pada rencana pembelajaran, seperti gambar 1 berikut.

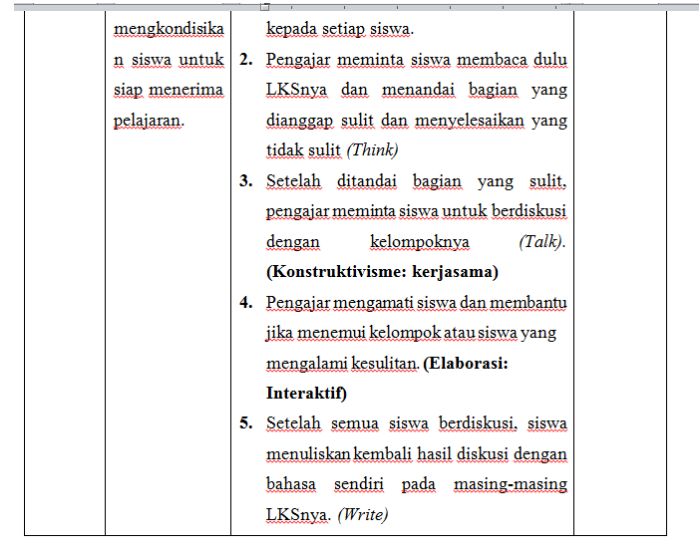

Gambar 1. Proses pembelajaran Think Talk Write

Pada rencana pelaksanaan pembelajaran tahap think ditunjukan pada saat siswa mengerjakan LKS yang telah diberikan, karena dalam tahap ini siswa secara individu memikirkan kemungkinan jawaban (strategi penyelesaian), membuat catatan kecil tentang ide-ide yang terdapat pada bacaan, dan hal-hal yang tidak dipahaminya sesuai dengan bahasanya sendiri. Kemudian tahap talk ditunjukan pada saat siswa berdiskusi tentang LKS yang sebelumnya sudah dikerjakan pada tahap think. Pada tahap ini siswa diberi kesempatan untuk membicarakan tentang penyelidikannya pada tahap pertama. Pada tahap ini siswa merefleksikan, menyusun, serta menguji (negosiasi, sharing) ide-ide dalam kegiatan diskusi kelompok. Selanjutnya pada tahap ketiga yaitu write ditunjukan ketika siswa menuliskan sendiri hasil yang diperoleh pada tahap sebelumnya. Tulisan ini terdiri atas landasan konsep yang digunakan, keterkaitan dengan materi sebelumnya, strategi penyelesaian, dan solusi yang diperolehnya.

Setelah kedua kelompok diberikan perlakuan yang berbeda, model pembelajaran Think Talk write pada kelas eksperimen dan model konvensional pada kelas kontrol. kedua kelompok tersebut diberikan tes kemampuan pemecahan masalah. Pada sebelumnya soal tes kemampuan pemecahan masalah matematis siswa tersebut telah diuji coba pada kelas uji coba, dari 10 soal uraian yang diujikan hanya 7 soal uraian yang digunakan. Dalam hal ini peneliti tidak menggunakan 3 soal uraian yang dibuang karena hasil uji validitas menyatakan 
bahwa ketiga soal uraian tersebut tidak valid, selain itu peneliti juga memertimbangkan waktu yang digunakan agar lebih efektif.

Salah satu soal yang digunakan dalam tes kemampuan pemecahan masalah matematis siswa ditunjukan pada gambar 2 berikut.

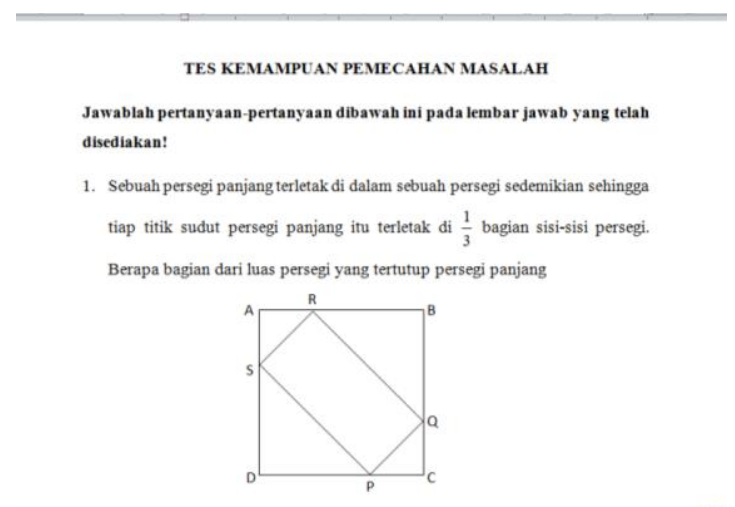

Gambar 2. Soal tes kemampuan pemecahan masalah matematis siswa

Sebuah soal dapat dikatakan sebagai soal pemecahan masalah jika memenuhi beberapa fase, yaitu memahami masalah, merencanakan penyelesaian, menyelesaikan masalah sesuai rencana, dan melakukan pengecekan kembali terhadap semua langkah yang telah dikerjakan.

Jadi soal di atas dapat dikategorikan soal pemecahan masalah dengan melihat hasil dari pengerjaan soal tersebut, hal itu dapat kita lihat pada gambar berikut.

Fase pertama yaitu, memahami masalah. Sepertihalnya gambar 3 di bawah ini, dimana siswa mengidentifikasi sebuah permasalahan yang diberikan dalam sebuah soal. Disini siswa menentukan apa permasalahan yang ditanyakan dan bagaimana pemecahan masalah yang diharapkan.

Fase kedua yaitu, merencanakan penyelesaian. Pada fase ini tidak dapat dibuktikan secara langsung dengan cara melihatnya. Fase ini nampak pada tahap-tahap atau strategi yang siswa pilih untuk menyelesaikan masalah tersebut.

Barulah pada fase ketiga yaitu, menyelesaikan masalah sesuai rencana, dapat dilihat secara jelas strategi yang dipikirkan siswa pada fase kedua tadi. Fase ketiga ini dapat kita lihat seperti pada gambar 4 .

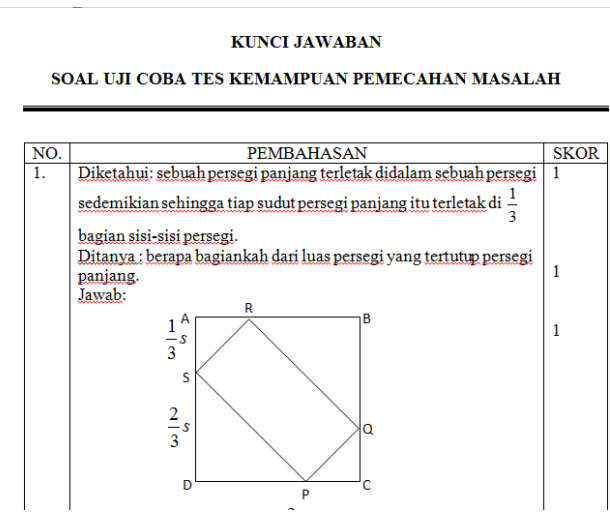

Gambar 3. Memahami masalah

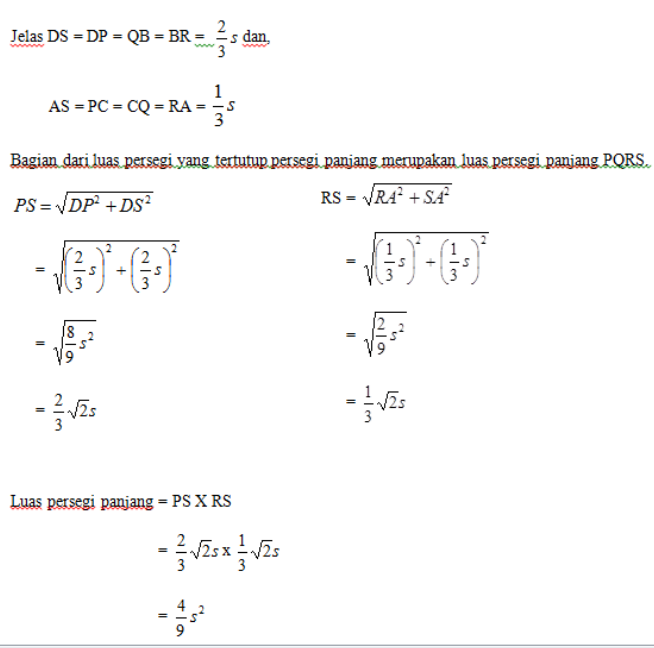

Gambar 4. Menyelesaikan masalah sesuai rencana.

Kemudian fase terakhir yaitu, melakukan pengecekan kembali terhadap semua langkah yang telah dikerjakan. Pada fase ini menunjukan apakah siswa melakukan pengecekan kembali terhadap jawaban selesaian masalah yang siswa kerjakan. Fase ini dapat dilihat pada bagian saat siswa memperjelas maksud dan tujuan awal menyelesaikan soal tersebut. Hal ini seperti yang terlihat pada gambar 5 .

Sebelum hasil dari tes kemampuan pemecahan masalah matematis siswa kelas kontrol dan kelas eksperimen digunakan untuk menjawab hipotesis penelitian, terlebih dahulu hasil dari tes kemampuan pemecahan masalah matematis siswa tersebut diadakan uji 
normalitas, dan uji homogenitas. Kemudian setelah itu barulah hasil tes kemampuan pemecahan masalah matematis tersebut digunakan untuk menjawab hipotesis, yaitu dengan melakukan uji ketuntasan belajar dan uji perbedaan dua rata-rata.

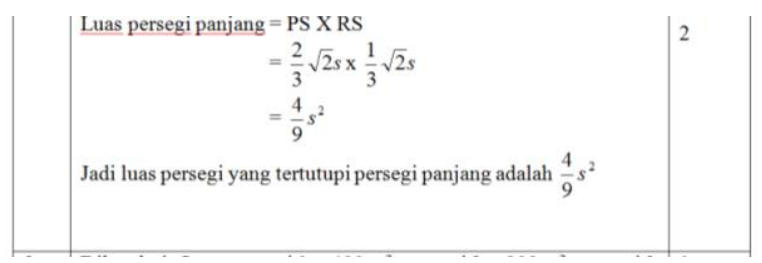

Gambar 5. Melakukan pengecekan kembali

Hasil uji ketuntasan pembelajaran kelas eksperimen adalah rata-rata skor tes kemampuan pemecahan masalah matematis kelompok eksperimen lebih dari atau sama dengan 85\% dengan KKM 75. Sedangkan hasil dari uji perbedaan dua rata-rata menunjukkan bahwa rata-rata skor tes kemampuan pemecahan masalah matematis kelas eksperimen lebih baik dari pada kelas kontrol, berarti rata-rata skor tes kemampuan pemecahan masalah matematis siswa dengan pembelajaran Think Talk write lebih baik dari pembelajaran konvensional.

Dari uraian diatas, hasil belajar siswa kelas eksperimen lebih baik dari pada hasil belajar kelas kontrol. Hal itu dikarenakan pada pembelajaran kelas eksperimen proses pembelajaran menggunakan model pembelajaran Think Talk Write. Pada awal penelitian ini dijelaskan bahwa metode penelitian menggunakan sistem random sampling, yaitu dengan mengambil sampel dari populasi yang ada, dengan begitu dapat dijelaskan bahwa keberhasilan menggunakan model pembelajaran Think Talk write dapat berlaku disetian kelas dalam populasi.

Model pembelajaran Think Talk write yang digunakan dapat memberikan hasil belajar yang baik bagi siswa, salah satunya digunakan dalam pembelajaran yang mengajarkan perlunya siswa menyelesaikan soal pemecahan masalah, dikarenakan pada pembelajaran ini siswa melaluai beberapa tahap. Tahap pertama yaitu Think, dimana siswa dituntut untuk 12 berpikir secara mandiri maslah yang harus diselesaikan serta strategi apa yang digunakan dalam memecahkan masalah tersebut. Kemudian pada tahap ke dua yaitu Talk, siswa diberikan kesempatan untuk berdiskusi dan mengemukakan pendapat dari hasil pemikiran siswa sendiri, barulah pada tahap Write, siswa dapat leluasa menuliskan sendiri hasil dari pemikiran serta diskusi-diskusi yang telah dilakukan dalam pembelajaran.

Dengan pembelajaran Think Talk write yang dilakukan secara bertahap dari hari kehari diharapkan dapat melatih siswa agar siap menghadapi dan dapat menyelesaikan soal pemecahan masalah dengan berbagai strategi. Pada penelitian ini peneliti menggunakan tiga hari untuk melakukan pembelajaran tersebut.

Seperti apa yang dikemukakan oleh Ansari [1] bahwa belajar dalam model pembelajaran Think Talk write memberikan kesempatan kepada siswa untuk memulai belajar dengan memahami permasalahan terlebih dahulu, kemudian terlibat secara aktif dalam diskusi kelompok, dan akhirnya menuliskan dengan bahasa sendiri hasil belajar yang diperolehnya.

Hal tersebut sesui dengan teori piaget yang menjelaskan bahwa tiga prinsip utama pembelajaran, yaitu belajar aktif (think), belajar lewat interaksi sosial (talk), dan belajar lewat pengalaman sendiri (write). Selain itu beberapa teori juga mendasari keberhasilan model pembelajaran ini, yaitu teori belajar vygotsky dan teori thorndike.

\section{Kesimpulan}

Dari pengujian didapat 35 siswa dari 42 siswa yang telah mencapai ketuntasan belajar dengan KKM 75. Hasil uji ketuntasan belajar menyatakan bahwa 83,3\% siwa telah mencapai ketuntasan belajar. Artinya kemampuan pemecahan masalah matematis siswa dengan model pembelajaran Think Talk write telah mencapai ketuntasan belajar. Selanjutnya dari perhitungan didapat rata-rata kemampuan pemecahan masalah matematis siswa kelas eksperimen adalah 84 dan untuk kelas kontrol adalah 78. Pada hasil uji perbedaan rata-rata

http://journal.unugiri.ac.id/index.php?journal=JaMES 
kemampuan pemecahan masalah matematis siswa, siswa yang mendapat pembelajaran dengan model pembelajaran Think Talk write berbeda secara signifikan bila dibandingkan dengan rata-rata kemampuan pemecahan masalah matematis siswa yang mendapat model pembelajaran konvensional. Hal ini menunjukkan penerapan model pembelajaran Think Talk write pada materi segiempat (keliling dan luas jajargenjang, persegi panjang, dan persegi) kelas VII SMP Negeri 1 Klambu lebih baik digunakan daripada model pembelajaran konvensional. Berdasarkan hasil penelitian diperoleh kesimpulan bahwa model pembelajaran Think Talk write terbukti efektif digunakan dalam pembelajaran materi pokok segiempat khususnya keliling dan luas jajargenjang, persegi panjang, dan persegi pada aspek kemampuan pemecahan masalah matematis siswa. Selain itu pada pembelajaran Think Talk write siswa juga terlibat interaktif dalam pembelajaran. Siswa bekerjasama dan berdiskusi dalam mengerjakan lembar kerja siswa. Setiap siswa berusaha melaksanakan kerja kelompok dengan baik. Jika siswa kurang jelas, mereka segera bertanya kepada guru. Interaksi siswa juga dapat dilihat pada rata-rata skor interaktif siswa sebesar 2,95 dengan ratarata persentase $73,71 \%$. Sesuai kriteria berarti siswa interaktif dalam pembelajaran dengan model Think Talk Write. Berdasarkan uraian di atas, dapat disimpulkan bahwa pembelajaran dengan menerapkan model pembelajaran Think Talk write lebih efektif untuk meningkatkan kemampuan pemecahan masalah siswa pada materi segiempat meliputi keliling dan luas jajargenjang, persegi panjang, dan persegi daripada model pembelajaran konvensional.

\section{Ucapan Terima Kasih}

1. Dr. Mulyono M. Si sebagai dosen pembimbing I

2. Drs. Darmo sebagai dosen pembimbing II Atas bimbingan beliau, peneliti dapat menyelesaikan penelitian dan penulisan artikel ilmiah ini.

\section{Referensi}

[1] Ansari, B. Menumbuh-kembangkan Kemampuan Pemahaman dan Komunikasi Matematik Siswa SMU Melalui Strategi Think-Talk-Write. Disertasi tidak diterbitkan. Bandung: Program Pascasarjana UPI Bandung. (2004).

[2] Arikunto, S. Prosedur Penelitian Suatu Pendekatan Praktik. Jakarta: PT Rineka Cipta. (2006).

[3] Soedjoko, E. Strategi "Think-Talk-Write" dengan tugas-tugas memaca untuk meningkatkan kemampuan pemecahan masalah matematika. Makalah disajikan dalam seminal Nasional dalam Rangka Konferensi Nasional Matematika XII di Universitas Negeri Semarang, Juli 2006. Semarang: Jurusan Matematika FMIPA Unnes (2006).

[4] Sukestiyarno. Olah Data Penelitian Berbantuan SPSS. Semarang. Universitas Negeri Semarang (2010). 
http://journal.unugiri.ac.id/index.php?journal=JaMES 